\title{
MASYARAKAT BIMA DALAM TEORI MENUJU MASYARAKAT HETEROGEN HERBERT SPENCER
}

\author{
Syukri Abubakar \\ Sekolah Tinggi Ilmu Tarbiyah (STIT) Sunan Giri Bima \\ Email, Syukri_ab@yahoo.com
}

\begin{abstract}
Abstrak
Masyarakat Bima sebagaimana masyarakat lainnya di dunia, memiliki sejarahnya sendiri dalam menapaki kehidupan. Sejarah telah mencatat bagaimana pasang surut kehidupan masyarakat Bima yang dimulai dari masa Naka dan Nchui, masa kerajaan dan kesultanan, hingga bergabung dengan NKRI. Tentu sejarah pertumbuhan dan perkembangan masyarakat Bima sangat berbeda dengan sejarah masyarakat daerah lainnya karena memiliki sejarah dan keunikan masingmasing.
\end{abstract}

Oleh karenanya, yang menjadi fokus dalam tulisan ini adalah bagaimana pertumbuhan dan perkembangan masyarakat Bima yang unik tersebut jika dikaitkan dengan teori menuju masyarakat Heterogen yang ditawarkan oleh Herbert Spencer. Dalam teorinya tersebut, ia menyatakan bahwa masyarakat itu berkembang secara evolutif bukan secara revolusi. Apakah masyarakat Bima termasuk dalam kategori masyarakat yang berkembang secara evolutif atau revolusi. Untuk menjawab hal itu, penulis mengumpulkan data pustaka baik berupa buku tentang Bima ataupun naskah-naskah kerajaan terkait.

Hasil penelitian menunjukkan bahwa masyarakat Bima mengalami pertumbuhan dan perkembangan secara evolutif sebagaimana yang dijelaskan oleh teori evolusi yang diwacanakan oleh Herbert Spencer. Evolusi tersebut dapat dilihat dari perubahan masyarakat yang homogen sejak masa Naka (pra sejarah), masa Ncuhi (proto sejarah atau ambang sejarah), masa klasik (masa pertengahan kerajaan), menuju masyarakat heterogen yang dimulai pada masa pertengahan kerajaan, masa kesultanan hingga bergabung dengan NKRI. Perubahan itu dapat dilihat dari cara mereka hidup, keyakinan yang dianut dan cara mereka membangun sistem pemerintahan pada tiap tahapnya.

Kata Kunci: Masyarakat Bima, Herbert Spencer, Teori Evolusi 


\section{Latarbelakang}

Bima adalah salah satu daerah yang terletak di bagian timur pulau Sumbawa di Propinsi Nusa Tenggara Barat. Penduduknya terdiri dari penduduk asli yang disebut dengan "dou mbojo", dan pendatang dari berbagai wilayah; Melayu, Arab, Makassar, Bugis, Cina, Flores, Jawa, Madura, Timor dan Maluku. Sebagian besar penduduknya beragama Islam. Jika diprosentasekan berkisar $95 \%$ beragama Islam, selebihnya Khatolik, Protestan, Budha, Hindu dan Konghucu.

Menurut catatan sejarah, masyarakat Bima pada mulanya mempercayai kekuatan gaib yang diistilahkan dengan "marafu". Kepercayaan ini berjalan sampai Islam masuk ke Bima sekitar abad ke 16 M. Daerah Bima dahulu dipimpin oleh lima orang Ncuhi. Ncuhi Dara memegang kekuasaan wilayah Bima Tengah, Ncuhi Parewa memegang kekuasaan wilayah Bima Selatan, Ncuhi Padolo memegang kekuasaan wilayah Bima Barat, Ncuhi Banggapupa memegang kekuasaan wilayah Bima Utara, dan Ncuhi Dorowoni memegang kekuasaan wilayah Bima Timur.

Kepemimpinan Ncuhi ini berakhir ketika seorang utusan dari Jawa bernama sang Bima berlayar ke arah timur dan mendarat disebuah pulau kecil disebelah utara Kecamatan Sanggar yang bernama pulau Satonda. Dialah yang mempersatukan kelima Ncuhi tersebut. Beliau menanamkan sendi-sendi dasar kerajaan berdasarkan Hadat. Setelah dirasa sudah cukup, maka beliau melanjutkan perjalanan ke arah timur sementara kepemimpinan para Ncuhi dipegang oleh Ncuhi Dara, hingga putra sang Bima yang bernama Indra Zamrud datang ke Bima pada abad XIV M dan diangkat menjadi raja (sangaji) pertama di kerajaan Bima. Untuk mengenang jasa sang Bima, namanya dijadikan nama daerah Bima sampai sekarang.

Setelah Islam masuk ke Bima, kerajaan Bima beralih menjadi kesultanan Bima yang berjalan secara turun temurun sejak tahun $1620 \mathrm{M}$ yang ditandai dengan diangkatnya putra mahkota Abdul Kahir sebagai sultan pertama. Kesultanan ini berakhir ketika daerah Swapraja dihapus di seluruh Indonesia dengan Undang-Undang no V tahun 1957. Seiring perkembangan zaman, saat ini 
daerah Bima sudah terbagi menjadi dua wilayah, yaitu Kota Bima dan Kabupaten Bima.

Terkait dengan pertumbuhan dan perkembangan masyarakat Bima dari masa Naka (Pra sejarah) ke masa Ncuhi (Proto Sejarah), jaman kerajaan (masa klasik) dan masa kesultanan (masa Islam) sampai sekarang, maka dalam tulisan singkat ini, penulis akan mengkaji berdasarkan teori evolusi masyarakat menuju masyarakat heterogen yang menjadi teori besar Herbert Spencer. Tulisan ini dimulai dengan uraian singkat latarbelakang Herbert Spencer yang dirangkaikan dengan teorinya "Menuju Masyarakat Heterogen". Uraian dilanjutkan dengan tahapan-tahapan yang dilalui oleh masyarakat Bima yang diawali dengan masa Naka dan Ncuhi sampai masa bergabung dengan NKRI. Terakhir, mengkaji keterkaitan teori "Menuju Masyarakat Heterogen" Herbert Spencer dengan pertumbuhan dan perkembangan masyarakat Bima dari masa ke masa.

\section{Herbert Spencer: Menuju Masyarakat Heterogen}

Herbert Spencer dilahirkan di Derby, Inggris, pada tanggal 27 April 1820. Dia dididik dalam bidang teknis dan praktis. Tidak dididik dalam bidang seni dan humaniora. Pada tahun 1837, dia mulai bekerja sebagai seorang insinyur sipil pada jasa kereta api, jabatan yang terus diembannya hingga tahun 1846. Selama periode tersebut, dia juga melanjutkan studinya sendiri dan mulai menerbitkan karya-karya ilmiah dan politis. ${ }^{1}$

Pada tahun 1848, Spencer diangkat sebagai seorang penyunting jurnal perdagangan bebas The Economist, disini ide-ide intelektualnya mulai menguat. Pada tahun 1850, dia telah menyelesaikan karya utamanya yang pertama yang berjudul Social Statics yang memprediksi bahwa manusia pada akhirnya akan menjadi benar-benar disesuaikan dengan kebutuhan di masyarakat dengan konsekuensi lenyapnya negara. Selama penulisan karya itu, dia mengalami insomnia untuk yang pertama kalinya, dan selama bertahun-tahun masalah mental 
dan fisiknya meningkat. Dia menderita serangkaian kemacetan saraf sepanjang sisa hidupnya. ${ }^{2}$

Salah satu sifat dia yang menyebabkan keruntuhan intelektualnya adalah ketidaksediaannya membaca karya orang lain. Sifat yang sama dimiliki oleh Auguste Comte, yang mempraktikkan "kebersihan otak". Spencer berpandangan bahwa jika ia membaca karya orang lain, maka dia hanya akan mengetahui sedikit saja dari ilmu pengetahuan. ${ }^{3}$ Maka muncul pertanyaan, dari manakah dia mendapatkan ide-ide dan wawasan?. Menurutnya, ide-ide dan wawasan itu muncul sedikit demi sedikit dengan cara-cara yang tidak mencolok tanpa maksud disengaja dan usaha yang besar.

Karena mengabaikan aturan-aturan ilmiah dalam penulisannya membuat dia menghasilkan serangkaian ide yang kasar dan penegasan-penegasan yang belum dibuktikan kebenarannya tentang evolusi dunia, sehingga para sosiolog abad ke 20 menolak karya Spencer dan menggantikannya dengan keilmiahan yang cermat dan riset yang empiris.

Dalam bukunya Sociology (New York: Appleton \& Co., 1892, Vol. 1), Spencer (1820-1903) mengungkapkan bahwa hukum perkembangan organisme merupakan hukum dari semua perkembangan. Teori yang dikemukakannya itu didasarkan pada konsep evolusi biologik Lamarck dan Darwin. ${ }^{4}$ Menurutnya, evolusi menjadi prinsip umum semua realitas: alam dan sosial. Adanya sifat umum (generality) karena realitas pada dasarnya adalah material yang terdiri dari zat, energi, dan gerakan. Evolusi didefinisikan sebagai perubahan dari homogenitas tak beraturan ke heterogenitas yang logis, yang diikuti kehilangan gerak dan integrasi zat. ${ }^{5}$

Singkatnya, bahwa proses evolusi sosial berlangsung melalui diferensiasi struktural dan fungsional sebagai berikut: Pertama, dari yang sederhana menuju

2Ibid.

3Ibid., 63

4Judistira K. Garna, Teori-teori Perubahan Sosial (Bandung: Program Pascasarjana Universitas Padjadjaran Bandung, 1993), 33.

5Piotr Sztompka, Sosiologi Perubahan Sosial. Ter. Alimandan cet. 7 (Jakarta: Prenadamedia Group, 2014), 119. 
yang kompleks; kedua, dari tanpa bentuk yang dapat dilihat ke keterkaitan bagianbagian; ketiga, dari keseragaman, homogenitas ke spesialisasi, heterogenitas; keempat, dari ketidakstabilan ke kestabilan. ${ }^{6}$ Proses seperti ini adalah universal. Dalam perkembangan bumi, semua kehidupan di atasnya, yakni masyarakat, pemerintahan, manufaktur, perdagangan, bahasa, literatur, ilmu pengetahuan, seni, dan seterusnya berlaku hukum evolusi yang sama; dari kesederhanaan ke bentuk yang kompleks, melalui diferensiasi.

Sehingga pada titik ini, Spencer berpandangan bahwa masyarakat adalah sebuah organisme ${ }^{7}$. Maksudnya ada kesamaan antara cara memandang masyarakat dengan cara memandang organisme biologis manusia. Menurutnya, masyarakat sebagai organisme biologis diartikan sebagai sesuatu yang selalu tumbuh dan berkembang melalui proses evolusi. ${ }^{8}$ Gagasan pertumbuhan ini memberikan gambaran pertama mengenai transformasi sosial dan menjadi landasan teori sosiologi maupun pemikiran berdasarkan akal sehat dan sangat populer hingga kini. ${ }^{9}$

Ia menjelaskan bahwa masyarakat tumbuh karena bertambahnya jumlah individu dan menyatunya kelompok-kelompok (perkumpulan) dalam kehidupan masyarakat. Peningkatan ukuran masyarakat membawa pada struktur sosial yang lebih besar dan lebih terdeferensiasi, sekaligus menciptakan peningkatan diferensiasi fungsi yang dimainkannya. Selain pertumbuhan ukuran, masyarakat berevolusi melalui percampuran, yaitu dengan semakin banyak menyatukan kelompok-kelompok yang berdekatan. Jadi, masyarakat tumbuh dari masyarakat sederhana, menuju masyarakat yang rumit, rumit rangkap dua dan rumit rangkap

6Ibid.

7Nanang Martono, Sosiologi Perubahan Sosial Perspektif Klasik, Modern, Posmodern, dan Pos Kolonial, edisi Revisi,(Jakarta: PT. Raja Gravindo Persada, 2014), 47.

8Ibid.

9Pertumbuhan berarti perluasan, perkembangan, komplikasi, dan diferensiasi. Pertumbuhan adalah proses yang (1) terdiri dari perkembangan kemampuan (potensi) yang sudah ada sejak awal di dalam diri obyek yang dikaji (membuka dan menunjukkan apa yang telah ada di dalam bibit atau embrio; (2) bergerak maju menuju satu arah dan tak dapat diubah (tak ada cara untuk kembali dari kedewasaan ke kemudaan); (3) kelangsungannya tak dapat ditawar-tawar dan tak dapat dihentikan (tak ada cara untuk tetap muda sebelumnya); (4) bergerak maju secara bertahap, meningkat setahap demi setahap; dan (5) tahap atau fase yang dilalui dapat dilihat (misalnya; muda, dewasa, tua). Lihat Piotr Sztompka, Sosiologi, 116. 
tiga. ${ }^{10}$ Proses perubahan yang umum tersebut menyebabkan perubahan seterusnya pada organisasi sosial, misalnya dari kelompok sukubangsa (tribe) kepemimpinan suku (chieftanship), seorang ketua dari kepala-kepala bagian dalam kumpulan sosial sekunder, dan sukubangsa yang lebih berkuasa itu meneguhkan ciri-ciri militer dengan penaklukan melalui peperangan atau mengadakan persahabatan dengan suku bangsa lainnya. ${ }^{11}$

Setelah kelompok demi kelompok itu dikonsolidasikan dalam satu pemerintahan, maka akan terjadi perserikatan antar kelompok. Proses sosial melahirkan ciri kompleksitas pada sistem kekuasaan dengan wujudnya kategorikategori: raja, kekuasaan atau pemerintah lokal, dan ketua kelompok kecil dan dalam waktu yang bersamaan, timbul pula pembagian kelas yang lebih tegas, seperti militer, pendeta dan budak. Perkembangan ini memperlihatkan evolusi struktur dan fungsi yang berbeda dalam masyarakat yang berskala besar dan kompleks, atau civilised nations. ${ }^{12}$

Jadi menurut Spencer, proses evolusi masyarakat itu melalui beberapa tahap perkembangan, yaitu: Pertama, tahap masyarakat sederhana. Masyarakat ini dicirikan dengan masyarakat yang terisolasi, aktivitas seluruh anggotanya serupa, tidak ada organisasi politik. Kedua, masyarakat kompleks, yang dicirikan dengan adanya pembagian kerja antarindividu, serta pembagian fungsi antar bagianbagian masyarakat yang mulai muncul, hierarki organisasi politik sangat penting. Ketiga, masyarakat lebih kompleks, yang dicirikan dengan adanya wilayah bersama, memiliki konstitusi dan sistem hukum permanen. Keempat, peradaban, yaitu sebuah kesatuan sosial yang paling kompleks, terbentuknya negara bangsa, adanya federasi beberapa negara atau diwujudkan dengan kekhaisaran yang besar. $^{13}$

Spencer juga menawarkan teori evolusi dari masyarakat militan menuju masyarakat industri. Masyarkat militan lebih awal digambarkan disusun untuk melakukan peperangan dalam rangka bertahan dan menyerang. Kendati spencer

10George Ritzer, Teori Sosiologi..., 60

11Judistira K. Garna, Teori-teori..., 34.

12Ibid.

13Piotr Sztompka, Sosiologi, 120. Liat juga Nanang Martono, Sosiologi..., 49. 
bersikap kritis terhadap perang, ia merasa pada tahap awal perang berfungsi menyatukan masyarakat (misalnya melalui penaklukan militer) dan menyediakan lebih banyak jumlah orang yang diperlukan bagi perkembangan masyarakat industri. Namun, dengan kemunculan masyarakat industri, perang semakin tidak fungsional dan justru menghambat evolusi lebih lanjut. Masyarakat industri didasarkan pada persahabatan, altruisme, spesialisasi kompleks, pengakuan atas prestasi daripada karakteristik yang dibawa sejak lahir, dan kerjasama sukarela antar individu yang sangat disiplin. Masyarakat semacam itu disatukan oleh hubungan kontraktual secara sukarela dan yang lebih penting lagi adanya kesamaan moralitas yang kuat. Peran pemerintah dibatasi dan difokuskan pada hal-hal yang tidak boleh dilakukan oleh individu atau orang. Karena jelas bahwa masyarakat industri modern kurang menyukai perang bila dibandingkan dengan masyarakat militan pendahulunya. Meskipun spencer melihat adanya evolusi umum yang bergerak ke arah masyarakat industri, ia pun mengakui bahwa mungkin akan terjadi adanya regresi periodik yang mengarah pada peperangan dan masyarakat militan. ${ }^{14}$

\section{Masa Pertumbuhan Masyarakat Bima}

Berdasarkan catatan $B O$ (catatan lama Istana Bima) yang dikutip oleh sejarahwan Bima M. Hilir Ismail bahwa sistem pemerintahan yang pernah tumbuh dan berkembang dalam sejarah kerajaan Bima ada tujuh masa pemerintahan. 1) masa Naka, 2) masa Ncuhi, 3) masa Kerajaan, 4) masa Kesultanan, 5) masa Swapraja, 6) masa Swatantra, dan 7) masa Kabupaten/Kota. ${ }^{15}$

Pada masa Naka tidak meninggalkan jejak tertulis yang bisa dijadikan rujukan. $B O$ (catatan lama Istana Bima) tidak menjelaskan secara detail mengenai zaman Naka, cuma disinggung bahwa sebelum masa ncuhi, masyarakat Bima hidup dalam zaman $\mathrm{Naka}^{16}$. Sekalipun demikian, masa pra sejarah ini, meninggalkan petilasan sejarah berbentuk alat-alat dari batu, tempat-tempat

14George Ritzer, Teori Sosiologi..., 60

15M. Hilir Ismail, Peran Kesultanan Bima dalam Perjalanan Sejarah Nusantara (Mataram: Lengge, 2004), 22.

16Ibid. 
pemujaan, peninggalan-peninggalan, kuburan-kuburan, purba dan lain-lain. Di pegunungan Doro Nocu Kecamatan Sape dan Tolo Donggo, misalnya, ditemukan lokasi pemujaan dan kuburan pra sejarah yang terdiri dari batu, yang dalam bahasa arkeologi disebut dolmen. Selain beberapa tempat pemujaan roh nenek moyang dan beberapa dolmen, juga ada yang berbentuk batu berundak-undak. Menurut sumber tradisi dalam masyarakat Bima bahwa dahulu ada istana wadu nteli (bahasa Bima; wadu artinya batu, nteli artinya tersusun; wadu nteli sebagai tempat pemujaan dan pemujaan roh nenek moyang). Fungsi dari wadu nteli (batu berundak-undak) dapat diketahui dari tulisan Nugroho yang menyatakan: "Punden berundak-undak merupakan tempat pemujaan. Biasanya pada punden berundakundak juga didirikan menhir. Bangunan ini artinya merupakan susunan batu yang berundak-undak". ${ }^{17}$

Dalam pemakaman mayatnya orang-orang dahulu mempunyai cara-cara tersendiri. Sebelum mayat dimasukkan ke dalam liang lahat, mayat tersebut diikat terlebih dahulu, tangan sampai kepala, bersama-sama harta miliknya, seperti tombak, senjata tajam, kemudian ditutupi dengan batu yang melebar. Lokasi ini dapat dilihat dari pegunungan Doro Nocu Sape dan di Doro Donggo. ${ }^{18}$

Kalau memperhatikan catatan mengenai masyarakat pra sejarah (jaman Naka) pada umumnya, masyarakat Bima pun pada jaman itu memiliki kemiripan cara hidup, yang masih sangat sederhana. Masyarakat hidup secara nomaden (mengembara), hidup berkelompok, setiap satu kelompok dipimpin oleh satu kepala suku, belum mengenal sistem ilmu pengetahuan dan teknologi, pertanian, peternakan, pertukangan atau perindustrian serta perniagaan dan pelayaran. Untuk memenuhi kebutuhan sehari-hari, mereka mencari dan mengumpulkan kekayaan alam yang ada disekitarnya seperti umbi-umbian, biji-bijian dan buah-buahan dan gemar berburu. Dalam istilah ilmu arkeologi, karena mereka mengumpulkan makanan dari hasil kekayaan alam disebut masyarakat pengumpul (Food Gathering). ${ }^{19}$

17Siti Maryam R. Salahuddin, dkk., Aksara Bima: Peradaban Lokal yang Sempat Hilang (Mataram: Alamtara Learning Society, 2013), 12. 18Ibid.

19 M. Hilir Ismail, Peran Kesultanan..., 23. 
Kepercayaan yang meraka anut pada masa itu disebut Makakamba dan Makakimbi, yang dalam ilmu sejarah disebut kepercayaan Animisme dan Dinamisme. Menurut mereka, alam beserta isinya diciptakan oleh Yang Maha Kuasa, disebut Marafu atau Tuhan. Marafu bersemayam di mata air, pohon-pohon besar atau batu-batu besar. Tempat bersemayamnya sering disebut Parafu Ro Pamboro, tempat dilakukannya upacara pemujaan. Upacara itu mereka sebut “Toho Dore". Dalam upacara pemujaan, dibacakan mantra atau do'a serta persembahan berupa sesajen dan penyembelihan hewan. Upacara dipimpin oleh seorang pemimpin yang disebut Naka.

Naka bukan hanya sebagai seorang pemimpin agama tetapi juga sebagai pemimpin dalam kehidupan sehari-hari. Naka sangat dihormati, sehingga masyarakat selain menyembah Marafu, juga sangat menghormati arwah leluhur seperti arwah Naka. Pada jaman ini, masyarakat sangat menjunjung tinggi asas Mbolo Ro Dampa (Musyawarah) dan Karawi Kaboju (Gotong Royong). Segala sesuatu selalu dimusyawarahkan.

Masa berikutnya adalah masa ncuhi. Tentang kehidupan pada zaman ncuhi, Bo Sangaji Kai menceritakan, ketika itu daerah Bima diperintah oleh kepala suku yang disebut $n c u h i$ yaitu tokoh masyarakat yang memiliki kekuatan kharismatik tradisonal. Wilayah Bima tersebut terbagi dalam lima wilayah kekuasaan ncuhi : Ncuhi Bolo, memegang kekuasaan wilayah Bima Barat; Ncuhi Dara, memegang kekuasaan wilayah Bima Tengah; Ncuhi Parewa, memegang kekuasaan wilayah Bima Selatan; Ncuhi Banggapupa, memegang kekuasaan wilayah Bima Utara dan Ncuhi Dorowuni, memegang kekuasaan wilayah Bima Timur.

Kelima ncuhi ini hidup berdampingan secara damai, saling hormat menghormati dan selalu mengadakan musyawarah mufakat bila ada sesuatu yang menyangkut kepentingan bersama. Dari kelima ncuhi tersebut yang bertindak selaku pemimpin dari ncuhi lainnya adalah ncuhi Dara.

Adapun struktur pemerintahan Ncuhi masih sangat sederhana dan belum lengkap, baik dilihat dari susunan maupun dari segi personalianya. Dalam 
pemerintahan hanya ada dua lembaga yang mengatur kehidupan masyarakat, yaitu; Ncuhi dan anggota masyarakat.

Sementara kehidupan masyarakat Bima pada masa ini masih hidup secara berkelompok-kelompok yang dipimpin oleh seorang Ncuhi berdasarkan pertalian darah keturunan atau kekeluargaan (paguyuban), yang dalam perkembangannya diikat oleh persekutuan wilayah (teritorial) dan perasaan senasib sepenanggungan. ${ }^{20}$

Pada masa-masa berikutnya, para ncuhi ini dipersatukan oleh seorang utusan yang berasal dari Jawa. Menurut legenda yang dipercaya secara turun temurun oleh masyarakat Bima, cikal bakal Kerajaan Bima adalah Maharaja Pandu Dewata yang mempunyai 5 orang putra, yaitu: Darmawangsa, Sang Bima, Sang Arjuna, Sang Kula, dan Sang Dewa.

Salah seorang dari lima bersaudara ini yakni; Sang Bima berlayar ke arah timur dan mendarat di sebuah pulau kecil di sebelah utara Kecamatan Sanggar yang bernama Satonda. Dalam catatan BO Sangajikai, dijelaskan bahwa sang Bima menikah dengan Puteri Sari Tasik Naga ${ }^{21}$ dengan memiliki dua orang putra yang diberi nama Maharaja Indra Komala dan Maharaja Indra Zamrud. Indra Zamrud kemudian tinggal dengan ncuhi Dara dan dijadikan anak angkat oleh ncuhi Dara, sedangkan Indra Komala tinggal dengan ncuhi Dorowuni dan kemudian hilang di oi Mbo.

Ketika Indra Zamrud dewasa, lima ncuhi di Bima sepakat mengangkatnya menjadi raja, sedangkan para ncuhi tersebut menjadi menteri. Dalam menjalankan roda pemerintahan, mereka mengamalkan system pemerintahan berdasarkan adat. Adat yang dilaksanakan dengan musyawarah dan semangat karawi kaboju (gotong royong). ${ }^{22}$

Dengan modal dasar tersebut, maka Indra Zamrud berhasil meletakkan dasar yang kokoh bagi pertumbuhan kerajaan Bima. Raja-raja Bima yang

20 Ibid., 26.

21 Dijelaskan bahwa putri naga ini adalah seorang manusia yang dikutuk dewa. Sebenarnya putri naga juga tidak mengetahui kalau yang mengawininya adalah ayahnya sendiri yaitu Sang Bima. Baru ia mengetahui setelah suatu hari ia menyisir rambut ayahnya dan kebetulan melihat luka dikuduknya akibat kejatuhan sebuah teropong alat tenun pada masa kecil. Lihat Henry Chambert -Loir, Kerajaan Bima dalam Sastra dan Sejarah Ceritera Asal Bangsa Jin dan Segala Dewa-dewa, Hikayat Sang Bima, Syair Kerajaan Bima (Jakarta: Ecole francaise d'Extreme-Orient dan yayasan Obor Indonesia, 2004), 53.

22 M. Hilir Ismail, Peran..., 35. 
memerintah sesudahnya seperti; Batara Indra Bima, Batara Sang Luka, Batara Sang Bima, Maharaja Mitra Indra Tarati, berhasil memperkuat dasar kerajaan. ${ }^{23}$

Pada akhir-akhir kepemimpinan Ncuhi, Bima sudah mulai mengadakan hubungan dengan daerah-daerah luar, terutama dengan Jawa, Sulawesi Selatan, dan Melayu. Hubungan ini terjalin melalui jalur perniagaan. Sejak masa pemerintahan raja Erlangga hingga sekitar abad XI, jalur perniagaan di Nusantara bagian timur menjadi ramai. Bima yang memiliki pelabuhan alam yang tenang, indah, dan strategis menjadi ramai untuk daerah persinggahan pelayaran antara Jawa dan Maluku. ${ }^{24}$

\section{Masa Perkembangan Masyarakat Bima}

Pada masa pemerintahan sangaji Manggampo Jawa raja Bima yang ke-8, sekitar abad ke 14 M, kerajaan Bima mengalami kemajuan yang amat pesat. Manggampo Jawa adalah putra sangaji Indra Tarati dengan permaisuri yang berasal dari bangsawan Majapahit. Ia banyak mengamati dan mempelajari perkembangan ilmu pengetahuan dan teknologi di daerah Jawa. Dari hasil pengamatannya itu, ia bertekad untuk mengembangkan pengetahuan dan teknologi tersebut di Bima. Untuk itu, ia mendatangkan khusus seorang ahli dari Majapahit bernama Ajar Panuli. Ia mengajari masyarakat Bima mengenai teknik pembuatan candi, pembuatan batu bata dan tulis menulis. ${ }^{25} \mathrm{Hal}$ ini dapat dibuktikan dengan adanya batu bata peninggalan Majapahit yang berada di kompleks pekuburan Sultan Bima di Tolobali.

Menurut ahli sejarah, pada masa itu pula sangaji Manggampo Jawa, merintis penulisan naskah kuno yang bernama $B O$ sebagai sumber sejarah Bima. $B O$ yang ditulis pada masa itu, memakai lontar dengan aksara Bima. Contoh aksara Bima tersebut dapat dilihat dalam buku History of Java karya T.S Raffles. Aksara tersebut tidak dipakai lagi. Ada kemungkinan, sebagaimana yang disinyalir oleh Henry Chamber-Lior, bahwa $B O$ tersebut sudah musnah terbakar sehingga tidak berbekas sampai sekarang. ${ }^{26}$

23Ibid., 37.

24Ibid., 28.

25Ibid.

26Menurut catatan Henry bahwa naskah-naskah kuno Bima banyak yang musnah akibat kebakaran. Kebakaran itu terjadi beberapa kali, yaitu pada masa pemerintahan Sultan Abdul 
Pada masa pemerintahan Raja Ma Wa'a Paju Longge ( \pm abad ke-15), yang menggantikan Maharaja Indera Seri, kerajaan Bima semakin berkembang. Ia seorang raja yang berpandangan luas dalam mewujudkan kemajuan kerajaan. Untuk mendukung itu semua, menurutnya perlu ada orang yang menguasai ilmu pengetahuan. Maka ia mengirim ke dua adiknya yang bernama Ma Wa'a Bilmana dan Manggampo Donggo ke Kerajaan Manurung di Sulawesi Selatan. Setelah bertahun-tahun menimba ilmu di sana, keduanya kembali ke Bima dan segera melakukan pembaharuan dalam segala bidang kehidupan dengan tetap mempertahankan adat yang berlaku.

Pada saat pemerintahan dijabat oleh mereka berdua, Manggampo Donggo sebagai Perdana Menteri dan Ma Wa'a Bilmana sebagai Raja (ke-16), atas kesepakatan mereka berdua, jabatan tersebut ditukar. Manggampo Donggo sebagai raja dan Ma Wa'a Bilmana sebagai Perdana Menteri. Agar kesepakatan tersebut tidak dilanggar dan ditaati oleh anak keturunannya kelak, maka diperkuat dengan sumpah. Sumpah itu dikenal sebagai Sumpah Ma Wa'a Bilmana dan Manggampo Donggo.Setelah itu, mereka mulai melakukan pembaharuan terutama dalam bidang ekonomi, kemelut pertahanan keamanan, politik pemerintah dan ilmu pengetahuan.

Dalam bidang ekonomi, memperluas daerah pertanian dengan membuat sawah-sawah di seluruh wilayah dan memperbaiki bendungan dan irigasi. Sebagian dari sawah dipergunakan untuk kepentingan kerajaan, dan jaminan penguasa hadat setempat yang disebut Dana Sara (sawah hadat). Sejak itu, Bima menjadi gudang beras setelah Lombok. ${ }^{27}$ Adapun daerah pegunungan dan dataran tinggi dijadikan hutan lindung yang berfungsi sebagai suaka margasatwa. Untuk menjaga keamanan hutang lindung diangkat seorang penjaga yang diberi nama Manenti Mpori. Dengan cara demikian, kelestarian hutan dan hewan seperti rusa, kerbau, kuda dan segala jenis burung terpelihara dengan baik.

Kadim (1751-1773) yang menyebabkan banyak dokumen lama yang hilang. Kebakaran berikutnya terjadi pada tanggal 1 Juli 1794 dan menurut ingatan orang Bima kini, kantor sekretariat istana pernah terbakar sekitar tahun 1938 yang menyebabkan Bo Bicarakai ikut terbakar. Naskah-naskah yang terbakar tersebut belum diketahui apakah ditulis menggunakan aksara Bima atau aksara Arab Melayu. Patut diduga bahwa aksara Bima juga digunakan dalam penulisan naskah tersebut. Lihat Henri Chambert-Loir, Bo' Sangaji... hal. xxxi.

27 Hilir Ismail, Peran..., 42. 
Dalam bidang keamanan, membentuk armada laut yang dipimpin oleh Laksamana Laut, yang disebut Rato Pabise. Armada Laut yang dirintis oleh Manggampo Donggo dan Ma Wa'a Bilmana merupakan cikal bakal dari armada laut yang berjaya dalam melawan kapal perang Portugis dan Belanda, pada masa kesultanan. Begitu juga armada darat disempurnakan dengan keterampilan personel dan organisasi. Armada darat mempunyai pasukan kavaleri (berkuda) di bawah pimpinan perwira yang disebut Jena Jara. Panglima laskar kerajaan dipimpin oleh Bumi Renda.

Dalam bidang politik pemerintahan, melakukan penyempurnaan dengan berpedoman pada sistem pemerintahan di Sulawesi Selatan. Kepala pemerintahan dipegang oleh raja dan Tureli Nggampo (perdana menteri) dibantu oleh lembaga Hadat. Lembaga Hadat, terdiri dari: 6 Jeneli, 12 Bumi Na'e. Struktur pemerintahan yang terus dipertahankan hingga masa kesultanan dengan perkembangan yang bervariasi sesuai dengan keadaan zaman.

\section{Masa Kesultanan Sampai Sekarang}

Masa kesultanan dimulai sejak La Kai putra Mahkota kerajaan atau Jena Teke dinobatkan sebagai sultan Bima pada tanggal 15 Rabiul Awal $1050 \mathrm{H}$. Peristiwa ini dalam $B O$ dicatat sebagai berikut:

"Hijratun Nabi Sallalahu'alaihi wasallam 1050 genap pada lima belas hari bulan Rabi'ul Awal Ruma Ta Mabata Wadu dinobatkan menjadi raja Kerajaan Bima".

Dengan penobatan tersebut, resmilah beliau menjadi sultan dengan penyerahan payung kerajaan yang terbuat dari daun lontar, keris kerajaan yang bernama "Keris Samparaja", dan mahkota. Penyerahan payung, keris dan mahkota kerajaan ini dilakukan oleh salah seorang bangsawan dari keturunan Bilmana. Orang itulah kelak yang akan dicalonkan menjadi Ruma Bicara (Perdana Menteri ${ }^{28}$.Tentang penyerahan mahkota kerajaan kepada La Ka-i Ruma Ta Mabata Wadu disebutkan dalam BO Tanah Bima:

"Dan Ruma Ta Lambila Menyerahkan payung lontar dan keris Samparaja kepada Ruma Ta Mabata Wadu dan menurut peran Rumata Ta Amalimandai Bicara Mambora Bacihu, Lambila. Demikianlah adanya”.

28M. Fachrir Rahman, Islam Di Bima Kajian Historis Islamisasi Era kesultanan, (Mataram: Alam Tara Institut, 2011), 69. 
Dengan dilantiknya La Ka-i menjadi raja Bima I dan penyerahan mahkota kerajaan oleh Lambila menurut hadat kerajaan, maka berakhirlah kerajaan Bima yang berjiwa Hindu yang dipimpin oleh sangaji dan sekaligus berdirilah kerajaan Bima yang berlandaskan Islam pada tanggal 15 Rabiul Awal 1050 H/5 Juli 1640 M dengan rajanya yang pertama Sultan Abdul Kahir yang bergelar Ruma Ta Mabata Wadu. Ia merupakan raja yang ke-26 dari susunan kerajaan Bima dan sultan yang pertama dalam urutan kesultanan Islam Bima. ${ }^{29}$

Ruma Ta Mabata Wadu menikah dengan adik dari isteri Sultan Makassar Alauddin bernama Daeng Sikontu, puteri Karaeng Kassuarang. Setelah Sultan Bima I Ruma Ta Mabata Wadu mangkat, digantikan oleh putranya yang bernama Sultan Abil Khair Sirajuddin sebagai Sultan Bima II, maka sistem pemerintahannya berubah dengan berdasarkan "Hadat dan Hukum Islam".

Beliau dilahirkan bulan April 1627 (Ramadhan 1038 H), bergelar Ruma Mantau Uma Jati. Ia juga bernama La Mbila, orang Makassar menyebut "I Ambela”. Wafat tanggal 22 Juli 1682 (17 Rajab 1099 H), dimakamkan di Tolo Bali. Menikah dengan saudara Sultan Hasanuddin, bernama Karaeng Bonto Je'ne, pada tanggal 13 September 1646 (22 Rajab 1066 H), di Makassar. Abdul Khair Sirajuddin dinobatkan menjadi Sultan Bima II, pada tahun $1640(1050 \mathrm{H})$.

Masa kesultanan ini berlanjut turun temurun sampai sultan yang ke 13 yang bernama Sultan Muhammad Salahuddin (1917-1950). Kesultanan Bima mengakhiri masa pemerintahan saat Indonesia merdeka 1945. Saat itu raja-raja Sumbawa memutuskan untuk bergabung ke dalam Republik Indonesia. Hal ini dilakukan mengikuti UU No 1 Tahun 1957 tentang penghapusan daerah swapraja.

Selanjutnya wilayah Bima dimekarkan menjadi Kota Bima dan Kabupaten Bima. Pada awalnya, pemilihan Bupati dan Walikota dipilih oleh rakyat melalui anggota DPRD Kabupaten/Kota Bima dan sejak reformasi, Bupati dan Walikota dipilih secara langsung oleh rakyat sampai sekarang.

\section{Masyarakat Islam Bima dalam Teori Evolusi Masyarakat}

Kalau kita kaitkan dengan teori evolusi masyarakat Herber Spencer, maka pada masa pertumbuhan masyarakat Bima yakni masa Naka dan Ncuhi, 
masyarakat Bima masuk dalam kategori tipe masyarakat homogen, karena masyarakat Bima pada kedua masa ini masih hidup nomaden (berpindahpindah), berkelompok-kelompok yang dipimpin oleh seorang kharismatik yang disebut Naka dan Ncuhi. Pada zaman ini masyarakat Bima belum memiliki ciriciri masyarakat heterogen, masyarakat yang kompleks, yang rumit, sebagaimana yang dimaksud oleh Spencer.

Dilihat dari sisi pekerjaan, mereka belum memiliki pekerjaan tetap. Mereka hanya berfikir bagaimana menyambung hidup mereka sehari-hari. Jenis pekerjaan yang mereka lakukakan untuk menyambung hidup adalah mereka mencari dan mengumpulkan kekayaan alam yang ada disekitarnya seperti umbiumbian, biji-bijian dan buah-buahan dan gemar berburu. Sedangkan dari sisi kepercayaan, mereka percaya terhadap, yang mereka sebut sebagai Makakamba dan Makakimbi, yang dalam ilmu sejarah disebut kepercayaan Animisme dan Dinamisme.

Adapun pada masa perkembangan dan masa kesultanan, masyarakat Bima mulai terlihat perkembangannya dalam beberapa bidang. Hal ini ditandai dengan usaha-usaha yang dilakukan oleh sangaji Manggampo Jawa dengan mendatangkan khusus seorang ahli dari Majapahit bernama Ajar Panuli untuk mengajari masyarakat Bima mengenai teknik pembuatan candi, pembuatan batu bata dan tulis menulis. Bahkan sejak itu, Manggampo Jawa merintis penulisan buku sejarah Bima yang biasa di sebut BO Sangajikai (buku catatan sejarah kerajaan Bima) dengan aksara Bima lama, walaupun $B O$ yang beraksara Bima lama tersebut, menurut Henri Chambert Loir dan St.Maryam R. Salahuddin, telah terbakar bersamaan dengan terbakarnya istana kerajaan Bima yang terjadi sebanyak dua kali. Namun catatan-catatan penting lainnya beraksarakan Arab Melayu baik berupa jilidan buku maupun berupa lembaran dan beberapa yang menggunakan aksara Bima baru, masih tersimpan rapi di Museum Samparaja Kota Bima.

Begitu juga usaha-usaha pengembangan yang dilakukan oleh Manggampo Donggo dan Ma Wa'a Bilmana dalam bidang ekonomi, pertanian, kehutanan, armada laut dan darat serta sistem pemerintahan yang berlaku. Kemudian dilanjutkan oleh sultan kedua yang bernama Abil Khair Sirajudin menggantikan sistem pemerintahan sebelumnya dengan sistem pemerintahan 
berdasarkan Hadat dan Hukum Islam. Perubahan-perubahan tersebut menunjukkan bahwa masyarakat Bima berevolusi menjadi masyarakat heterogen.

Jadi pada masa perkembangan dan masa kesultanan, masyarakat Bima sudah mulai mengalami perubahan. Dari sisi pekerjaan, mereka sudah mengenal teknologi pertanian, pertukangan dan ilmu pengetahuan, sehingga jenis pekerjaan bermacam-macam. Ada yang menjadi petani, pelaut, pedagang, pengajar dan lainlain. Keyakinannya pun berubah setelah raja yang ke-26 yang bernama La Mbila masuk Islam berubah nama menjadi Abdul Kahir. Ia mengajak semua rakyatnya memeluk agama Islam. Mendengar ajakan rajanya tersebut, semua rakyat masuk Islam kecuali sebagian yang melarikan diri di daerah pegunungan bagian Barat dan bagian Timur yang saat ini disebut dengan Donggo Di dan Donggo Ele. Untuk masyarakat Donggo Ele saat ini sudah memeluk Islam 100\%, sementara masyarakat Donggo Di ada yang menganut agama Islam dan ada yang menganut Agama Katolik dan Protestan. Wallahu a'lam.

\section{Catatan Akhir}

Dari uraian di atas dapat disimpulkan bahwa menurut catatan sejarah dan bukti-bukti sejarah bahwa masyarakat Bima mengalami beberapa tahap perubahan sistem pemerintahan secara evolutif yang dimulai pada masa Naka (pra sejarah), masa Ncuhi (proto sejarah atau ambang sejarah), masa klasik (masa kerajaan), masa kesultanan sampai saat ini. Perubahan itu dapat dilihat dari cara mereka hidup, keyakinan yang dianut dan membangun sistem pemerintahan pada tiap tahap.

Jika dikaitkan dengan teori evolusinya Herbert Spencer, maka masyarakat homogen bisa dilihat pada masa Naka (pra sejarah) dan masa Ncuhi (proto sejarah) dan masa awal kerajaan. Sementara mulai pada masa pertengahan kerajaan, yaitu masa pemerintahan Sangaji Manggampo Jawa raja Bima yang ke-8, sekitar abad ke $14 \mathrm{M}$, kerajaan Bima mengalami kemajuan yang amat pesat dan begitu seterusnya pada masa Kesultanan, masa Swapraja, masa Swatantra, hingga masa Kabupaten/Kota menunjukkan perkembangan masyarakat yang mengarah kepada masyarakat yang heterogen. Wallahu a'lam. 


\section{DAFTAR PUSTAKA}

BO Tanah Bima (Naskah Arab Melayu Peninggalan Kesultanan Bima).

George Ritzer, Teori Sosiologi dari Sosiologi Klasik sampai Perkembangan Terakhir Postmodern. Edisi VIII, cet. II, Yogyakarta: Pustaka Pelajar, 2014.

Henri Chambert-Loir, Bo’ Sangaji Kai Catatan Kerajaan Bima, Jakarta: Ecole francaise d'Extreme-Orient dan yayasan Obor Indonesia, 1999.

, Kerajaan Bima dalam Sastra dan Sejarah Ceritera Asal Bangsa Jin dan Segala Dewa-dewa, Hikayat Sang Bima, Syair Kerajaan Bima, Jakarta: Ecole francaise d'Extreme-Orient dan yayasan Obor Indonesia, 2004.

Judistira K. Garna, Teori-teori Perubahan Sosial, Bandung: Program Pascasarjana Universitas Padjadjaran Bandung, 1993.

M. Fachrir Rahman, Islam Di Bima Kajian Historis Islamisasi Era kesultanan, Mataram, Alam Tara Institute, 2011.

M. Hilir Ismail, Peran Kesultanan Bima dalam Perjalanan Sejarah Nusantara Mataram: Lengge, 2004.

Nanang Martono, Sosiologi Perubahan Sosial Perspektif Klasik, Modern, Posmodern, dan Pos Kolonial, edisi Revisi, Jakarta: PT. Raja Gravindo Persada, 2014.

Piotr Sztompka, Sosiologi Perubahan Sosial. Ter. Alimandan cet. 7, (Jakarta: Prenadamedia Group, 2014.

Siti Maryam R. Salahuddin, dkk., Aksara Bima: Peradaban Lokal yang Sempat Hilang (Mataram: Alamtara Learning Society, 2013. 2013.

Hukum Adat Undang-undang Bandar Bima, Yogyakarta: Lengge, , Hukum Adat Tanah Bima dalam Perspektif Hukum Islam, Yogyakarta: Lengge, 2013. 